\title{
Workplace aesthetics: impact of environments upon employee health as compared to ergonomics
}

\author{
Elisabet Schell ${ }^{1}$, Tores Theorell ${ }^{2}$, and Helena Saraste ${ }^{1}$ \\ ${ }^{1}$ Karolinska Institutet, Department of Molecular Medicine and Surgery, S-171 77 Stockholm, Sweden ${ }^{2}$ \\ Karolinska Institutet, Center for Health Sciences, S-71 77 Stockholm, Sweden ${ }^{3}$ Stress Research Institute \\ Stockholm University, S-106 91 Stockholm, Sweden
}

\begin{abstract}
Associations between self-reported needs for aesthetic and ergonomic improvements were studied to analyse a possible impact of aesthetic needs on job performance as compared to ergonomic needs in 11 occupational groups. Employees at Swedish broadcasting company were invited to participate in a cross sectional study. $74 \%$ ( $\mathrm{n}=1961 / 2641)$ fulfilled the inclusion criteria. Demographic data from company files and a pre-validated questionnaire were used. 'High rank' and 'low rank' aesthetic and ergonomic needs were compared. The perceived needs for aesthetic and ergonomic improvements showed significantly different distributions $(p<0.001)$. Aesthetic needs were more frequently reported. No gender related differences were observed. Differences between occupational groups were shown $(\mathrm{p}=0.006,0.003)$.'High rank' needs for aesthetic and ergonomic improvements were similarly associated to psychological demands, stress, pain and age. 16/24 factors showed significant differences between 'high and low rank' aesthetic needs, whereas 21/24 between ergonomic needs. Sick leave was stronger related to ergonomics. The study results show a relation between not only work place ergonomics but also work place aesthetics to health and well-being. Future work health promotion and prevention may benefit from the inclusion of workplace aesthetics.
\end{abstract}

Keywords: Aesthetics, ergonomics, work environment, musculoskeletal pain, low back pain, occupational health, stress, sickleave

\section{Introduction}

There is little empirical evidence of the influence of design and workplace aesthetics on employees and the distance between ergonomic, psychological factors, and the architectural design process can be considerable $[10,11,19,31]$.

Already in 1972 Maslow and Mintz [28] described the effect of aesthetics of workers levels of energy and their overall well-being. Mintz 1972 also studied the effects of aesthetic surroundings by prolonged and repeated experience in "beautiful" and "ugly" room [31]. Similar studies have been made in hospital environments $[7,12,13,44]$. Dilani $[13,14]$ studied work environment's influence on hospital staff, and Caspari et al (8] studied patient's opinion of healthy hospital environments. "Recent studies on aesthetics on other workplaces are rare.

Ergonomics, an integral part of workplace design, is related to occupational health, safety, and job satisfaction $[1,3,5,16,29,33,35,41]$. Leather et al 1998 [22] includes effects of sunlight in the work-place on employees and the stress item. Perceived environmental attributes, neighbourhood and workplace design characteristics are associated with well-being and job satisfaction [10, 32]. In addition to ergonomics and work organisation an aesthetically supportive and harmonious physical environment may influence employees' views of their workplaces and their own health $[11,14,26$, 27]. According to Helander 2005 [19] the work

\footnotetext{
Corresponding author: Elisabet Schell e.schell@telia.com $+468251319 ; 0706702069$
} 
chair's design, aesthetics and comfort might be as important as its ergonomic advantages.

Aesthetic and ergonomic factors, with or without psychosocial effects can be perceived to overlap $[19,22,25,41,42,43]$. In the clinical praxis ergonomic problems are often focused on. The question arises if the comprehension of aesthetic needs only reflects the ergonomic needs. To differentiate between those two is important in prevention of work place problems.

\section{Study design}

The present study is a part of an employee survey performed at the Swedish Public Service Broadcasting Company (Swedish Television) and the Radio Symphony Orchestra (Swedish Radio) regarding employees' needs for aesthetic and ergonomic improvements. A cross- sectional design was employed.

Two hypotheses were tested:

1. there will be no significant associations between perceived aesthetic improvements and occupational position, work environment and organisation, health and demographic variables set ups

2. the distribution of responses to the perceived need for aesthetic improvements will not be significantly different to the need for ergonomic improvements.

\section{Method}

\subsection{Participants}

All employees at the Public Service Broadcasting Company for Television Swedish Television) and at the Radio Symphony Orchestra ( Swedish Radio), who had been employed for the previous 12 months and were not on leave for more than 6 months (e.g. for studies, childbirth, sickness or work abroad), were asked to participate in a survey. The inclusion criteria were fulfilled by 2641 employees and 1961 of them agreed to respond to the questionnaire giving a response rate of $74 \%$. Occupational position, age, gender, and sick leave for the previous 12 months were collected from company files. The sick-leave for the total television company was $3.6 \%$ at the time for the current study as compared to the national average $5.6 \%$, as measured the same way the same period. The sick-leave rate in the study population was even lower due to the inclusion criteria (long term sick-listed excluded) [37, 39].

The participants worked in a wide variety of environments. The Swedish Television and the Swedish Radio have access to occupational health similarly to the praxis in other larger companies. Work-stress due to re-organisation and tight deadlines is common in these work settings.

\subsection{Survey}

The questionnaire distribution was performed by mail. Two reminders were sent if needed. The questionnaire design was chosen in accordance with company consent, time efficacy and in- accordance to Ruguliers [26, 36]. The questions used in this survey had earlier been used by Statistics Sweden [37], in their repeated national studies on living conditions, and by the Standardised Nordic Questionnaire [21] all of which are pre-validated questionnaires. Scales were either visual analogue (VAS 0-10) [30], or Likert-type [24].

A four-week test-retest for repeatability of additional questions was performed within the study. Of the 40 persons randomly selected for this purpose 32 participated $(80 \%)$. The test-retest correlations were significant $(\mathrm{p}<0.001$ to 0.007 , Spearman's correlation test). The correlation mean was $\mathrm{r}=0.74$ with median $\mathrm{r}=0.71$ (upper $25 \%=1$ to 0.83 ; middle $50 \%=0.82-0.58$; lower $25 \%$ 0.570.47).

The groups of variable set ups included demographic data, work environmental and health factors (such as sick-leave, stress-related symptoms and musculoskeletal pain).

Questions on perceived need for aesthetic and ergonomic improvements were included among other questions and did not therefore induce a specific response bias. The questions were: 1) 'Do you consider that your workplace aesthetic environments need to be improved?' - the response alternatives were: 'yes, definitely', 'yes, to a high degree' (dichotomized to 'high rank'); 'yes, to some degree', and 'no, not at all' (dichotomized to 'low rank') and 2) 'Do you consider that your workplace ergonomic environments need to be improved?' The response alternatives were: 'yes, definitely', 'yes, to a high degree' (dichotomized to 'high rank); 'yes, to some degree', and 'no, not at all' (dichotomized to 'low rank'). The aesthetic and ergonomic needs for improvements were outcome variables. The definition of workplace aesthetics varies $[10,11,13,19,40]$. In this survey we asked for the subjectively perceived needs to obtain data for future more detailed studies. The ergonomic needs were equally handled e.g. no definition was given.

\section{Data Analysis}

The McNehmar test was used to compare the response distribution of the needs for "aesthetic" and "ergonomic" improvements respectively within 
the total group, and the 'sign test' between occupations [2].

The responses to the aesthetic needs and ergonomic needs were dichotomized to 'high rank' and 'low rank'. The other 'Likert-type' scales were dichotomised to "yes" and "no".

Responses to the questions on pain in the neck, shoulder, upper or low back (VAS 0-10) were summed as the variable "total sum of pain" (score 0-40) and with other musculoskeletal pain (VAS 010) included (score 0-50). Similarly the questions on the pain relatedness to stress (scale 0-3, score 012 ) and to work posture/load (scale 0-3, score 0-12) were summed and dichotomized $(0=\mathrm{No} ; \geq 1=$ Yes $)$.

Comparisons of means were performed with Student's independent t-test, and one-way analyses of variance. ANOVA with post hoc tests were used to compare means between groups. The Chi-square test was used to compare differences in distribution between ordered groups with more categories than two. The comparison were corrected for multiplicity according to the "least significant difference" (SPSS Base 9.0). Age was adjusted for.

Post hoc analysis were performed separately for aesthetic needs and for ergonomic needs respectively between occupational groups. Bon Ferroni corrections were included.

All analyses were made with a confidence interval of $95 \%$. The two-tailed $\mathrm{p}$-value $<0.05$ was regarded as significant when no other comment was given.

The study was approved by the Ethical Research Committee North at Karolinska Institutet (Dnr 02199). All participants gave informed consen.t

\section{Results}

The total number of participants in the survey was 1961. This corresponds to a participation rate of $74 \%$ (70-86\% in occupational subgroups). Seventytwo \% responded to the separate question on aesthetics $(\mathrm{n}=1905)$ and $73 \% \quad(\mathrm{n}=1917)$ to the question on ergonomics. The mean age was 47.67 yrs (range $21-67, \pm$ SD 10.5), 42\% were women and $58 \%$ men. There were no significant differences between participants and drop-outs with regard to age, gender or occupation; nor were there any differences in participation rate between employees at headquarters or those stationed elsewhere in Sweden. Educational background and occupation groups are described in Table 1.

According to the company's sick-leave register, $53 \%$ of the study participants had no sick-days at all (47\% of the women, and $58 \%$ of the men). Those with no sick-days were younger 46.5 yrs (SEM 0.36) than those with sick-days 48.8 yrs (SEM 0.32). The mean difference was 2.3 yrs $(\mathrm{p}<0.001)$.
The distribution of the responses to the question on need for aesthetic improvements was: yes, definitely $27 \%$; yes, to a high degree $19 \%$; yes, to some degree; $36 \%$; no, not at all $18 \%$. Thus, $46 \%$ ranked 'high need' for aesthetic improvements, Table 2. There were no significant gender related differences.

The distribution of the responses to the question on need for ergonomic improvements was: yes, definitely $16 \%$; yes, to a high degree $18 \%$; yes, to some degree $49 \%$; no, not at all $17 \%$. Thus, $34 \%$ ranked 'high need' for ergonomic improvements, Table 2. There were no significant gender related differences.

\subsection{Occupational groups}

The distribution of responses to aesthetic need for improvements was significantly different distributed between the 11 occupational groups $(\mathrm{p}<0.001$; Qui-square=85.0), Table 3 and Figure 1 . Seven out of 15 were similar as for ergonomic needs.

Also the distribution of responses to ergonomic need for improvements was significantly different distributed between the 11 occupational groups $(\mathrm{p}<0.001$; Qui square=58.5), Table 3 and Figure 1 . Seven out of 13 were similar as for aesthetic needs

There were no significant gender related differences. 
Table 1

Educational background and occupational groups ( $\mathrm{n}=1961)$.

\begin{tabular}{|l|c|}
\hline Education & \% of total \\
\hline Compulsory school (9 yrs) & 4.8 \\
Upper-secondary school or professional education (16 yrs) & 19.9 \\
More specific professional education & 17.2 \\
College/University BA (16 yrs) & 31.3 \\
University MSc (>16 yrs) & 7.2 \\
Missing information & 19.6 \\
Total & \% of total \\
\hline Occupational groups & 16.3 \\
\hline 1. Administration & 4.3 \\
2. Persons with high executive position & 3.6 \\
3. Chief persons reporting to (2) & 3.9 \\
4. Studio and work room professionals (e.g. masks-, wigmakers, carpenters, painters, & \\
costume-makers, tailors and assistants & 9.7 \\
5. Picture/sound/light technicians & 7.3 \\
6..Cameramen\& "video" editors & 19.0 \\
7. Persons working directly with TV productions & 25.8 \\
8. Reporters, programme leaders and editorial staff & 1.8 \\
9. IT staff & 4.0 \\
10. Research and development technicians & 3.8 \\
11. Symphony orchestra & 0.3 \\
Missing information & 100.0 \\
Total & \\
\hline
\end{tabular}

Table 2

Distribution of the responses to the two questions: "Do you consider that your workplace aesthetics/ergonomics, respectively, need to be improved?"

\begin{tabular}{|c|c|c|c|c|c|c|}
\hline & $\begin{array}{l}\text { Aesthetic } \\
\text { needs } \rightarrow\end{array}$ & Yes definitely & $\begin{array}{l}\text { Yes, to a high } \\
\text { degree }\end{array}$ & $\begin{array}{l}\text { Yes, to some } \\
\text { degree }\end{array}$ & $\begin{array}{l}\text { No, not at } \\
\text { all }\end{array}$ & Total \\
\hline \multicolumn{7}{|l|}{$\begin{array}{l}\text { Ergonomic } \\
\text { needs } \\
\downarrow\end{array}$} \\
\hline Yes definitely & & 190 & 46 & 56 & 13 & 305 \\
\hline $\begin{array}{l}\text { Yes, to a high } \\
\text { degree }\end{array}$ & & 116 & 84 & 104 & 32 & 336 \\
\hline $\begin{array}{l}\text { Yes, to some } \\
\text { degree }\end{array}$ & & 167 & 200 & 398 & 173 & 938 \\
\hline No, not at all & & 32 & 36 & 117 & 135 & 320 \\
\hline Total & & 505 & 366 & 675 & 353 & 1899 \\
\hline
\end{tabular}

11092 / 1899 (58\%) responded differently with a significant difference between the response distribution to the two questions' four separate response alternatives $(p<0.001)$.

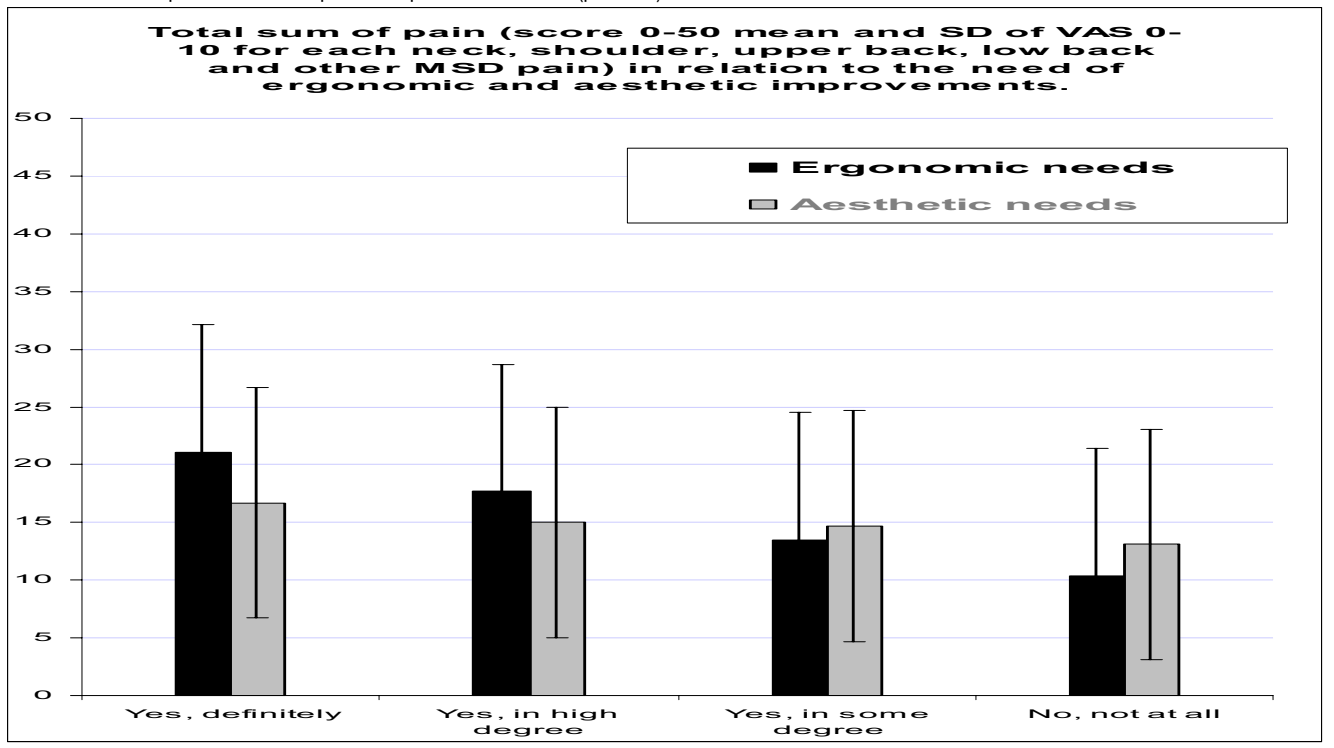

Fig 2. Mean values and SD of total sum of pain (score 0-50 e.g. VAS 0-10 for each of neck-shoulder-upper/low back and other musculoskeletal pain) distributed by response alternative of need for aesthetic and ergonomic improvements. 
Table 3

Distribution of 'high rank' need responses for aesthetic and ergonomic improvements in 11 ccupational groups ( $\mathrm{n}=1961$ ). Aesthetics: between occupational groups Qui-square $=85.0 ; \mathrm{p}<0.001$. Ergonomics: between occupational groups Qui square $=58.5 ; \mathrm{p}<0.001$ adjusted according to Bon Ferroni. Significant $\mathrm{p}$-values between separate occupational groups are given.

\begin{tabular}{|c|c|c|c|c|c|c|}
\hline Occupational groups & $\begin{array}{c}\text { Aesthetics: } \\
\text { high rank need } \\
\text { for } \\
\text { improvements } \\
\%\end{array}$ & $\begin{array}{l}\text { Ergonomic: } \\
\text { high rank } \\
\text { need for } \\
\text { improvements } \\
\%\end{array}$ & $\begin{array}{l}\text { Aesthetics } \\
\text { post hoc } \\
\text { between } \\
\text { groups }\end{array}$ & $\begin{array}{c}\text { Aesthetics } \\
\text { between } \\
\text { groups } \\
\text { p-value }\end{array}$ & $\begin{array}{c}\text { Ergonomics } \\
\text { post hoc } \\
\text { between } \\
\text { groups }\end{array}$ & $\begin{array}{l}\text { Ergonomics } \\
\text { between } \\
\text { groups } \\
\text { p-value }\end{array}$ \\
\hline $\begin{array}{l}\text { 1. Administration } \\
\text { 2. Persons with high executive } \\
\text { position } \\
\text { 3. Chief persons reporting to 2) } \\
\text { 4. Studio and work room } \\
\text { professionals (mask, } \\
\text { costume- makers, tailors and } \\
\text { assistants, wigmakers, } \\
\text { carpenters, painters) } \\
\text { 5. Picture/sound/light } \\
\text { technicians } \\
\text { 6. Cameramen\& "video" } \\
\text { editors } \\
\text { 7. Persons working directly } \\
\text { with TV productions } \\
\text { 8. Reporters, programme } \\
\text { leaders and editorial } \\
\text { 9. IT staff } \\
\text { 10. Research and develop- } \\
\text { ment technicians } \\
\text { 11. Symphony orchestra } \\
\text { Missing information } \\
\text { Total }\end{array}$ & $\begin{array}{c}33.5 \\
24.0 \\
\\
41.5 \\
41.7 \\
- \\
- \\
- \\
53.5 \\
\\
40.1 \\
50.9 \\
- \\
53.4 \\
- \\
28.6 \\
29.5 \\
- \\
69.3 \\
- \\
46\end{array}$ & $\begin{array}{c}26.1 \\
13.2 \\
28.6 \\
39.4 \\
- \\
- \\
- \\
43.9 \\
\\
47.4 \\
36.0 \\
- \\
39.6 \\
- \\
17.1 \\
17.8 \\
- \\
24.7 \\
- \\
34\end{array}$ & $\begin{array}{l}1 \text { vs } 5 \\
\frac{1 \text { vs } 7}{1 \text { vs } 8} \\
1 \text { vs } 11 \\
\frac{2 \text { vs } 4}{2 \text { vs } 5} \\
\frac{2 \text { vs } 7}{2 \text { vs } 8} \\
\frac{2 \text { vs } 11}{5 \text { vs } 10} \\
\frac{6 \text { vs } 11}{7 \text { vs } 10} \\
8 \text { vs } 10 \\
9 \text { vs } 11 \\
10 \text { vs } 11\end{array}$ & $\begin{array}{r}<0.001 \\
<0.001 \\
<0.001 \\
<0.001 \\
0.028 \\
<0.001 \\
<0.001 \\
<0.001 \\
<0.001 \\
0.016 \\
0.003 \\
0.028 \\
0.004 \\
0.006 \\
<0.001\end{array}$ & $\begin{array}{l}1 \text { vs } 6 \\
1 \text { vs } 7 \\
1 \text { vs } 9 \\
2 \text { vs } 4 \\
2 \text { vs } 5 \\
2 \text { vs } 6 \\
2 \text { vs } 7 \\
2 \text { vs } 8 \\
5 \text { vs } 10 \\
6 \text { vs } 9 \\
6 \text { vs } 10 \\
6 \text { vs } 11 \\
8 \text { vs } 11\end{array}$ & $\begin{array}{r}0.002 \\
<0.001 \\
0.006 \\
0.016 \\
<0.001 \\
<0.001 \\
0.004 \\
<0.001 \\
0.004 \\
0.003 \\
0.001 \\
0.032 \\
0.017\end{array}$ \\
\hline
\end{tabular}

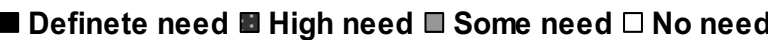
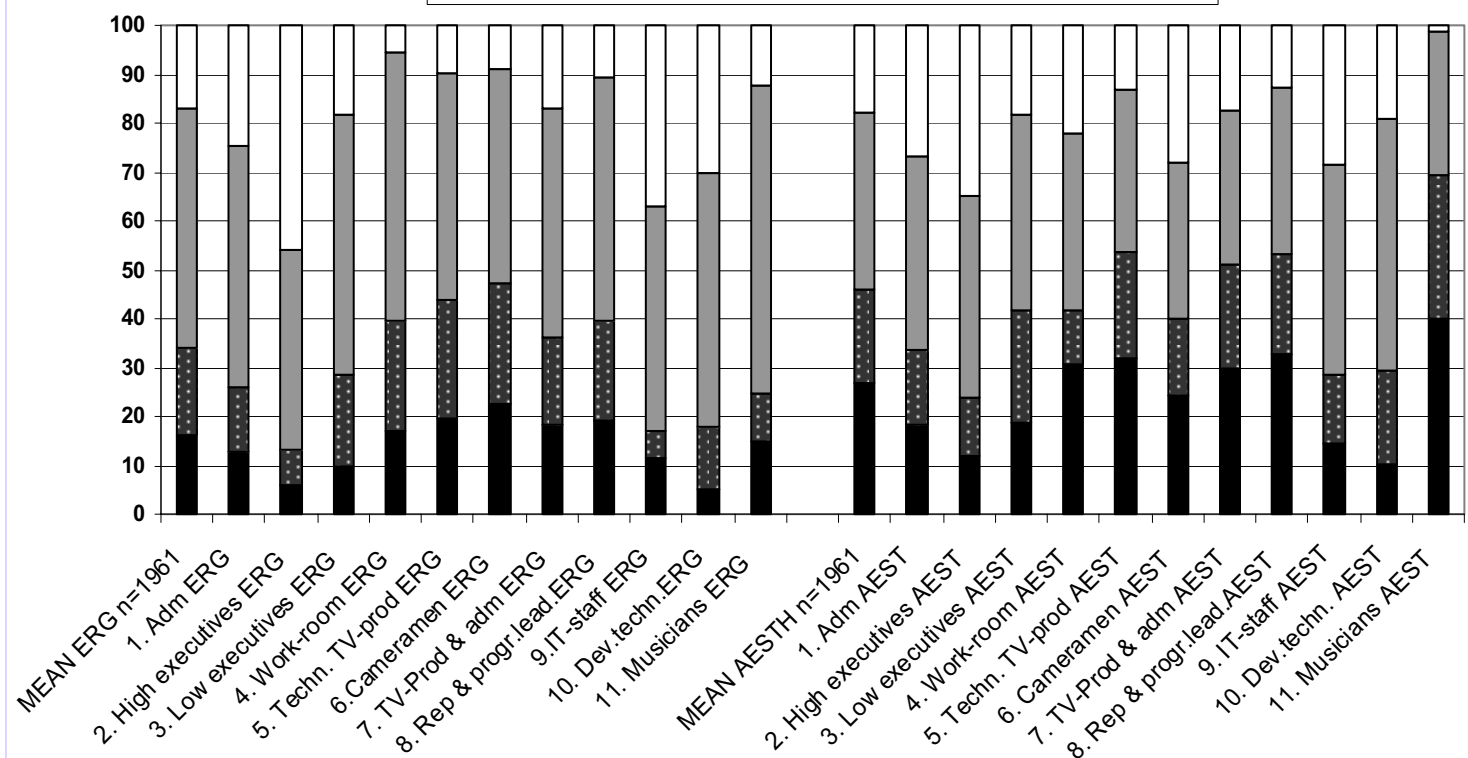

Fig 1. Distribution of responses to 'need for ergonomic improvements' and aesthetics respectively in 11 occupational groups 
Table 4

Differences between 'high rank' and 'low rank' need for aesthetic improvements with regard to demographic data,work environment and organisation, and health factors in 1905 employees. ${ }^{1 /}$

\begin{tabular}{|c|c|c|c|}
\hline Variable & $\begin{array}{l}\text { High rank need } \\
\text { for aesthetic } \\
\text { improvements } \\
n=874(46 \%) \\
\% \text { or mean }( \pm S D)\end{array}$ & $\begin{array}{l}\text { Low rank need } \\
\text { for aesthetic } \\
\text { improvements } \\
n=1031(54 \%) \\
\% \text { or mean }( \pm S D)\end{array}$ & p-value \\
\hline $\begin{array}{l}\text { Demographics } \\
\text { Gender: Female / Male } \\
\text { Education: Less high/High }{ }^{1} \\
\text { Negative stress outside work, yes }{ }^{2} \\
\text { Physical training (Yes/No); yes } 30 \text { min twice/weekly or more } \\
\text { General living conditions (VAS 0-10; from low to high) } \\
\text { Age (yrs) }\end{array}$ & $\begin{array}{l}44.3 / 47.0 \\
43.0 / 49.7 \\
50 \\
47.7 \\
7.1( \pm S D 1.79) \\
46.3( \pm \text { SD } 10.7) \\
\end{array}$ & $\begin{array}{l}55.7 / 53.0 \\
57.0 / 50.3 \\
44 \\
44.9 \\
6.9( \pm S D 1.87) \\
48.8( \pm S D 10.3) \\
\end{array}$ & $\begin{array}{l}0.254 \\
0.008 \\
0.004 \\
0.232 \\
0.075 \\
<0.001\end{array}$ \\
\hline $\begin{array}{l}\text { Work environment and organisation } \\
\text { Negative work stress, yes (Yes/No) }{ }^{2} \\
\text { Problems at work, yes (Yes/No) }{ }^{2} \\
\text { Perceived pain relatedness to stress, yes (neck-shoulder-upper and low back) }{ }^{4} \\
\text { Perceived pain relatedness to work posture/load, yes (as above) }{ }^{3} \\
\text { Disturbing noise, yes (Yes/No) } \\
\text { Irregular working hours, yes }{ }^{4} \\
\text { Psychologically demanding work (Yes/No) } \\
\text { Physically demanding work (Yes/No) } \\
\text { General influence on own work (VAS 0-10; end points "from low-high") } \\
\text { Dissatisfaction with work circumstances (VAS 0-10; end points "from low-high") }\end{array}$ & $\begin{array}{l}78.5 \\
63.8 \\
70.6 \\
82.8 \\
58.4 \\
59.8 \\
75.8 \\
22.2 \\
4.96( \pm \text { SD } 2.46) \\
5.82( \pm \text { SD } 2.72)\end{array}$ & $\begin{array}{l}70.3 \\
58.2 \\
64.1 \\
78.3 \\
41.6 \\
51.4 \\
62.8 \\
23.1 \\
5.41( \pm S D 2.47) \\
5.01( \pm S D 2.78)\end{array}$ & $\begin{array}{l}<0.001 \\
0.012 \\
0.003 \\
0.014 \\
<0.001 \\
<0.001 \\
<0.001 \\
0.656 \\
<0.001 \\
<0.001\end{array}$ \\
\hline $\begin{array}{l}\text { Health factors } \\
\text { Sick-leave occurrence for any reason, yes (yes/no - company file) } \\
\text { Sick leave for stress/depression, yes (yes/no) } \\
\text { Sick leave for musculoskeletal pain, yes (yes/no; neck-shoulder-upper and low back) } \\
\text { Sleep disturbances, yes (yes/no) }{ }^{2} \\
\text { Anxiety, yes (Yes/No) } \\
\text { Worry for own health lately, yes (yes/no) } \\
\text { Pain occurrence in neck-shoulder-upper and low back, yes (yes/no) }{ }^{5} \\
\text { Pain level in neck-shoulder-upper and low back (VAS 0-10; score } 0-40)^{5}\end{array}$ & $\begin{array}{l}45.9 \\
9.7 \\
8.5 \\
57.7 \\
60.1 \\
65.8 \\
88.3 \\
13.28( \pm \text { SD 9.79) }\end{array}$ & $\begin{array}{l}47.7 \\
7.4 \\
6.6 \\
49.9 \\
58.1 \\
70.6 \\
84.7 \\
11.87( \pm \text { SD 9.74) }\end{array}$ & $\begin{array}{l}0.423 \\
0.080 \\
0.113 \\
0.001 \\
0.495 \\
0.145 \\
0.024 \\
0.002\end{array}$ \\
\hline
\end{tabular}

1)_Table 4 and 5 Response alternatives: 1 Less high education level (9 -12 yrs, and specific occupational education $<16$ yrs); High education ( $\geq 16$ yrs college/university) 1 Yes, definitely; Yes often; Rarely; No, not at all (dichotomized: Yes/No)3 Working evenings and/or weekends once a week or more (Yes/No)4 No, not at all, Yes, to some degree, Yes, to a high degree; Yes, definitely (scale 0-3, score 0 -12; dichotomized No=0; Yes $\geq 1) 5$ Pain in neck, shoulder, upper and low back (VAS 0-10; score 0-40; No=0; Yes $\geq 1$ ) 
Table 5

Differences between 'high rank' and 'low rank' need for ergonomic improvements with regard to demographic data, work environment and organisation, and health factors in 1917 employees. ${ }^{1)}$

\begin{tabular}{|c|c|c|c|}
\hline Variable & $\begin{array}{l}\text { High rank need } \\
\text { for ergonomic } \\
\text { improvements } \\
n=874(46 \%) \\
\% \text { or mean ( } \pm S D)\end{array}$ & $\begin{array}{l}\text { Low rank need } \\
\text { for ergonomic } \\
\text { improvements } \\
n=1031(54 \%) \\
\% \text { or mean }( \pm S D)\end{array}$ & p-value \\
\hline $\begin{array}{l}\text { Demographics } \\
\text { Gender: Female / Male } \\
\text { Education: Less high/High } 1 \\
\text { Negative stress outside work, yes }{ }^{2} \\
\text { Physical training (Yes/No); yes } 30 \text { min twice/weekly or more } \\
\text { General living conditions (VAS 0-10; from low to high) } \\
\text { Age (yrs) }\end{array}$ & $\begin{array}{l}35 / 33 \\
33 / 35 \\
52 \\
45 \\
6.83( \pm \text { SD } 1.89) \\
46.3( \pm \text { SD 10.7) }\end{array}$ & $\begin{array}{l}65 / 67 \\
67 / 65 \\
44 \\
47 \\
7.13( \pm \text { SD } 1.78) \\
48.8( \pm S D 10.26)\end{array}$ & $\begin{array}{c}0.331 \\
0.470 \\
<0.001 \\
0.518 \\
0.001 \\
<0.001\end{array}$ \\
\hline $\begin{array}{l}\text { Work environment and organisation factors } \\
\text { Negative work stress, yes (Yes/No) }{ }^{2} \\
\text { Problems at work, yes (Yes/No) }{ }^{2} \\
\text { Perceived pain relatedness to stress, yes (neck-shoulder-upper and low back) }{ }^{4} \\
\text { Perceived pain relatedness to work posture/load, yes (as above) }{ }^{4} \\
\text { Disturbing noise, yes (Yes/No) } \\
\text { Irregular working hours, yes } 3 \\
\text { Psychologically demanding work (Yes/No) } \\
\text { Physically demanding work (Yes/No) } \\
\text { General influence on own work (VAS 0-10; end points "from low-high") } \\
\text { Dissatisfaction with work circumstances (VAS 0-10; end points "from low-high") }\end{array}$ & $\begin{array}{l}83.0 \\
68.7 \\
78.4 \\
90 \\
65 \\
59 \\
76.5 \\
30.8 \\
4.67( \pm \text { SD 2.4) } \\
6.29( \pm \text { SD 2.53) }\end{array}$ & $\begin{array}{l}69 \\
56.3 \\
61.3 \\
75 \\
42 \\
53 \\
64.5 \\
18.6 \\
5.47( \pm \text { SD } 2.46) \\
4.90( \pm \text { SD } 2.78)\end{array}$ & $\begin{array}{l}<0.001 \\
<0.001 \\
<0.001 \\
<0.001 \\
<0.001 \\
0.033 \\
<0.001 \\
<0.001 \\
<0.001 \\
0.003\end{array}$ \\
\hline $\begin{array}{l}\text { Health factors } \\
\text { Sick-leave occurrence for any reason, yes (yes/no - company file) } \\
\text { Sick leave for stress/depression, yes (yes/no) } \\
\text { Sick leave for musculoskeletal pain, yes (neck-shoulder-upper and low back) } \\
\text { Sleep disturbances, yes (yes/no) }{ }^{2} \\
\text { Anxiety, yes (Yes/No) } \\
\text { Worry for own health lately, yes (yes/no) } \\
\text { Pain occurrence in neck-shoulder-upper and low back, yes (yes/no) }{ }^{5} \\
\text { Pain level in neck-shoulder-upper and low back (VAS 0-10; score } 0-40)^{5}\end{array}$ & $\begin{array}{l}50.3 \\
9.4 \\
11.0 \\
63 \\
64 \\
60.4 \\
93 \\
16.22( \pm \text { SD 10.24) }\end{array}$ & $\begin{array}{l}45.0 \\
6.5 \\
7.3 \\
49 \\
57 \\
72.6 \\
83 \\
10.59( \pm \text { SD 8.98) }\end{array}$ & $\begin{array}{c}0.027 \\
0.023 \\
0.005 \\
<0.001 \\
0.002 \\
<0.001 \\
<0.001 \\
<0.001 \\
\end{array}$ \\
\hline
\end{tabular}

\subsection{Demographics}

There were significant differences between 'high rank' and 'low rank' responders in need for aesthetic improvements regarding the following variables: education, stress outside work and age $(\mathrm{p}<0.001-0.008)$. The results are shown in Table 4.

There were significant differences between 'high rank' and 'low rank' responders in need for ergonomic improvements regarding the following variables: stress outside work, general living conditions and age $(p<0.001-0.001)$. The results are shown in Table 5.

There were no gender nor physical training related differences between 'high rank' and 'low rank' responders in any of the studied groups, Table 4 and 5.

\subsection{Work environment and organisation}

There were significant differences between 'high rank' and 'low rank' responders in need for aesthetic improvements in nine out of ten work environmental and organisational variables $(\mathrm{p}<0.001-0.014)$, of which the following can be mentioned in specific: work stress, disturbing noise, irregular work hours and psychologically demanding work $(p<0.001)$. The results are shown in Table 4.

There were significant differences between 'high rank' and 'low rank' responders in need for ergonomic improvements in ten out of ten work environmental and organisational variables $(p<0.001-0.033)$. The magnitude of the differences were more obvious than in aesthetics. The results are shown in Table 5.

\subsection{Health factors}

There were significant differences between 'high rank' and 'low rank' need for aesthetic improvements in three out of eight health variables. Those were: sleep disturbances, pain occurrence and pain level $(\mathrm{p}<0.001-0.024)$. The results are shown in Table 4.

There were significant difference between 'high rank' and 'low rank' need for ergonomic 
improvements in all health variables $(p<0.001$ 0.027). The results are shown in Table 5.

The level of total sum of neck-shoulder-back pain and other musculoskeletal pain on one hand, and need for aesthetic and ergonomic improvements respectively according to all four response alternatives on the other hand, are given in Fig 2.

\subsection{Comparison between aesthetic and ergonomic response distributions}

The distribution of all four response alternatives to each of the questions 'need for aesthetic and need for ergonomic improvements' differed significantly $(\mathrm{p}<0.001)$. The numeric of 1092 out of 1899 (58\%) responded differently, Table 2. After dichotomization there were $46 \%$ 'high rank' responses to need for aesthetic improvements and $34 \%$ 'high rank' responses to need for ergonomic improvements $(\mathrm{p}<0.001)$ in the total study group. The distribution of dichotomized responses according to occupational groups are shown in Table 3.

\subsection{Main findings}

The main finding in the current study was that there were significant differences between 'high rank' and 'low rank' responses to need for aesthetic improvements with regard to demographic, work environment and organisation, and health factors. Thus the first study hypothesis was rejected.

The responses to aesthetic and ergonomic needs for improvements showed significantly different distributions in the total group as well as between occupational groups. The reported need for aesthetic improvements showed a higher frequency of 'high rank' responses than the need for ergonomic improvements did. The second hypothesis was rejected too.

\section{Discussion}

The current study is a large survey on a working population. The cross-sectional design and use of questionnaire have known limitations. Selfreporting is a method called into question by Heinrich et al [18] for measuring work load, whereas it is recommended by Dane et al [9] as very useful for studies of ergonomic exposure. According to Rugulies et al [36] the questionnaire as a study method for large population groups is superior. Linton reported in 2005 [25] that crosssectional and prospective questionnaire studies showed similar results. In this explorative study the purpose was to capture subjective evaluations and therefore the aesthetics and ergonomics were not defined in detail. The decision to leave respondents to judge what was meant by work-place aesthetics $[8,11,13,40]$ and ergonomics should be considered when interpreting the results.

Differences between 'high rank' and 'low rank' responses to need for aesthetic improvements with regard to demographic, work environment and organisation, and health factors were significant. These differences in health and disease were fewer and weaker, than for ergonomics.

Psychologically demanding work and irregular working hours were slightly more articulated for aesthetics than for ergonomics, whereas sleep disturbances, disturbing noise, pain and pain relatedness to stress and to work posture/load were articulated for both. Psychologically demanding work is earlier shown to be related to work environment and health factors [20, 23, 25, 33, 41, $42,43]$. The aesthetics' relation to psychologically demanding work in the current study might represent an additional work environmental factor with possible influence on productivity and health. Sleep disturbances, which are shown to be associated to several psychosocial factors, health, demand, control, and emotional support in accordance to Nordin et al 2005 [34] and Fahlén et al 2006 [17] include adverse consequences of effort-reward imbalance to sleep. Our findings might cautiously indicate that sleep disturbances also could be associated with work place aesthetics.

Disturbing and high noise level is documented as a risk factor for hearing damage. Danielsson [10] reported disturbing noise as a negative factor in open office environments. In stressful jobs, editorial open surroundings and office landscapes, which are often forecoming in the current study population, the subjectively perceived "ugly" work places might increase.

Stress at work and outside work and pain factors were associated to both 'high rank' aesthetic and ergonomic needs, though less so to aesthetics. These factors' relations to ergonomics are earlier documented [1, 25, 32, 41, 43]. The current results indicate that stress and pain might influence perceived need for aesthetic improvements too.

'High rank' responders of both aesthetic and ergonomic needs for improvements were significantly younger, in numeric values slightly, though. The results might point to a higher sensitivity among younger persons to be considered in work health prevention [29].

There were no significant gender differences, neither differences with regard to regular physical training, which activity is considered to support well-being and health according to some studies [6, 38 , and thus could have been expected to increase 
positive responses. However, there is also contradictory review documentation by Hambergvan Reenen $\mathrm{H}$ et al in 2008 [15]. Our findings seem to be in line with the last mentioned.

Sick-leave, physically demanding work, worry for own health and anxiety were significantly associated to ergonomic needs which is in accordance with earlier studies [1, 16, 25, 32, 33].

The current study group, with persons on long term sick-absenteeism excluded, represents a healthy, normal-employee population [1, 37, 39]. Still, differences were found in the studied variables representing negative occupational health factors $[1,4,16,23,26,32,33,34]$ between 'high and low rank' responders to need for aesthetic improvements.

The reported need for aesthetic and ergonomic improvements overlapped only partially. This finding indicates an independent role of "aesthetic" needs as an important work-environmental factor. In specific this was seen among musicians: nearly $70 \%$ of them reported need for aesthetic improvements, whereas less than $25 \%$ of them reported need for ergonomic improvements. Differences were also reported between several other occupational groups. In the independent post hoc tests only partial overlapping was shown between occupational groups. More numerous significant differences between occupations were found for aesthetic needs.

Whether or not the studied population is more sensitive to aesthetics than professional employees in general is beyond our judgement. The high ranking by musicians is of interest, though. In the current study, which was a first step in studying work place aesthetics, we looked for differences which might be of functional relevance. It can be pointed out that for instance psychologically demanding work, pain, stress, sleep disturbances and disturbing noise were significantly correlated to higher aesthetic demands. Their relation to work health is earlier well documented $[10,17,20,25$, $26,33,34]$. The current study shows a relation between work place aesthetics and health \& wellbeing, work environments and demographic conditions. Thus, the inclusion of work place aesthetics in work environment improvements and health promotion is an issue to consider.

\section{Future implications}

Empirical research of the role of "aesthetics" in work places and of it's impact on productivity is limited. Capturing the subjective evaluations of perceived aesthetic need for improvements and the differences between 'high rank' and 'low rank' groups on work environment and health might constitute a base for further studies. The perceived need for "aesthetic" improvements was independent from that for "ergonomic" improvements, which indicates that health management may benefit onthe-job-productivity if expanded to target workplace "aesthetics".

\section{Conclusion}

'High rank' perceived need for aesthetic improvements as compared to 'low rank' showed associations to stress, sleep disturbances, problems at work, psychologically demanding work, musculoskeletal pain, and age. Gender and physical training did not differ between 'high and low rank' responders, whereas occupational status did.

The independently tested associations were similar to, but fewer than those for ergonomic needs with regard to the variable set ups: demographics, work environment and health. Sick leave and pain was stronger related to ergonomics. The response distribution of need for aesthetic improvements was differently distributed from the need for ergonomic improvements. Future work health promotion and prevention might benefit from the inclusion of an assessment of workplace aesthetics.

\section{References}

[1] Alexandersson K (chairman). The Swedish Council on Technology Assessment in Health Care. Prescribed sick leave - causes, consequences and physician's certification practice. A systematic literature review. 2003. Report No 167, Product-id 167E. (www.sbu.se)

[2] Altman D, Practical statistics for medical research, 1994 ( $4^{\text {th }}$ ed. London Chapman \& Hall)

[3] Amick B.C 3rd, Robertson M M, De Rango K, Bazzani L, Moore A, Rooney T, Harrist R. Effect of office ergonomics intervention on reducing musculoskeletal symptoms. Spine 2003;28:2706-11

[4] Anema, JR, Cuelenaere B, van der Beek, AJ, Knol DL, de Vet HC, van Mechelen W. The effectiveness of ergonomic interventions on return-to-work after low back pain; a prospective two year cohort study in six countries on low back pain patients sick-listed for 3-4 months. Occupational and Environment Medicine 2004;61:289-94

[5] Arnetz BB, Sjogren B, Rydéhn B, Meisel R., , Early workplace intervention for employees with musculoskeletal-related absenteeism: a prospective controlled intervention study. Journal Occupational Environmental Medicine 2003;45:499-506

[5] Bernaards CM, Jans MP, van den Heuvel SG, Hendriksen IJ, Houtman IL, Bongers PM. Can strenuous leisure time 
physical activity prevent psychological complaints in a working population? Occup Environ Med 2006;63:10-6

[6] Caspari S, Eriksson K, Nåden D. The aesthetic dimension in hospitals - an investigation into strategic plans. J Nurs Stud 2006;43:851-9

[7] Caspari S, Nåden D, Eriksson K. Why not ask the patient? An evaluation of the aesthetic surroundings in hospitals by patients. Qual Manag Health Care 2007;16:280-92

[8] Dane D, Feuerstein M, Huang GD, Dimberg L, Ali D, Lincoln A. Measurement properties of a self-report index of ergonomic exposures for use in an office work environment. Journal of Occupational and Environment Medicine 2002;44:73-

[9] Danielsson K. Office Environment, Health \& Job Satisfaction: An explorative study of Office Design's Influence. Licentiate thesis in Technology and Health. Stockholm, Sweden 2005. Article in: Licentiate thesis in Technology and Health. Stockholm, Sweden, ISBN:917178-168-4

[10] Dekker SW, Nyce JM. How can ergonomics influence design? Moving from research findings to future systems. Ergonomics 2004;47:1624-39

[12] Dilani A. Psychosocially supportive design-Scandinavian health care design. World Hospital and Health Service 2001;37:20-4, 33-35

[13] Dilani A. Healthcare buildings as supportive environments.

World Hospital and Health Service 2000;36:20-6

[14] Dilani A. A new paradigm of design and health in hospital planning. World Hosp Health Serv 2005;41:17-21.

[15] Hamberg-van Reenen HH, Ariëns GA, Blatter BM, van Mechelen W, Bongers PM. A systematic review of the relation between physical capacity and future low back and neck/shoulder pain. Pain 200; 130:93-107

[16] Hansson T, Jensen I. Swedish Council on Technology Assessment in Health Care (SBU). Chapter 6. Sickness absence due to back and neck disorders. Scand J Public Health Suppl 2004;63:109-51

[17] Fahlén G, Knutsson A, Peter R, Akerstedt T, Nordin M, Alfredsson L, Westerholm P . Effort-reward imbalance, sleep disturbances and fatigue. Int Arch Occup Environ Health 2006;79:371-8

[18] Heinrich J, Blatter BM, Bongers PM. A comparison of methods for the assessment of postural load and duration of computer use. Occupational and Environment Medicine 2004;61:1027-31.

[19] Helander M. Forget about ergonomics in chair design? Focus on aesthetics and comfort! Ergonomics 2003;Oct 20-Nov 15;46:1306-19

[20] Karasek R, Theorell T. Healthy work. Stress productivity, and the reconstruction of working life 1990 (New York, Basic books, inc.)

[21] Kuorinka I, Jonsson B, Kilbom A, Vinterberg H, BieringSorensen F, Andersson G, Jorgensen K. Standardised Nordic question-naires for the analysis of musculoskeletal symptoms. Applied Ergonomics 1987;18:233-237 Leather P, Pyrgas M, Beale D \& Lawrence C. Windows in the workplace: Sunlight, view, and occupational stress. Environment and Behaviour 1998;30:739-762

[22] Leroux I, Dionne CE, Bourbonnais R. Psychosocial job factors and the one-year evolution of back-related functional limitations. Scandinavian Journal of Work Environment Health 2004;30:47-55

[23] Likert R. A technique for the development of attitudes scales. Educational and Psychological measurements 1952;12:313-15Linton SJ. Do psychological factors increase the risk for back pain in the general population in both a cross-sectional and prospective analysis? Eur $\mathrm{J}$ Pain 2005;44:73-8

Linton SJ. A review of psychological risk factors in back and neck pain. Spine 2000;25:1148-56.

[24] Lowe GS, Schellenberg G, Shannon HS. Correlates of employees' perceptions of a healthy work environment. American Journal of Health Promotion 2003;17:390-9

[25] Maslow AH, \& Mintz N L. Effects of aesthetic surroundings: Initial short-term effects of three aesthetic conditions upon perceiving "energy" and "well-being" in faces. In.Gutman (Ed.), People and buildings (pp. 212219) 1972; New York: Basic Books

[26] May DR, Reed K, Schroeder CE, Potter P. Ergonomic office design and aging: a quasi-experimental field study of employee reactions to an ergonomics intervention program, Journal of Occupational Health Psychology 2004; 9:123-35

[27] McCormack HM, Horne DJ, Sheather S: Clinical application of visual analogue scales: a critical review: Psychol Med 1988;18:1007-1019

[28] Mintz NL. Effects of aesthetic surroundings: 2. Prolonged and repeated experience in a "beautiful" and an "ugly" room. In Gutman R (Ed.), People and buildings 1972, (pp. 220-228). New York: Basic Books'

[29] Music S, Hook D, Banner S, Spooner M, Erdington DEW. The association of corporate work environment factors, health risks, and medical conditions with presenters among Australian employees. Am 2006; 21:127-36

[30] Nachemson A (chairman). The Swedish Council on Technology Assessment in Health Care. Neck and Back pain. A systematic review, 2000. Report No 145, Productid 145E, (www.sbu.se)

[31] Nordin M, Knutsson A, Sundbom E, Stegmayr B. Psychosocial factors, gender, and sleep. J Occup Health Psychol 2005; 10:54-63

[32] Robertson MM, O'Neill MY. Reducing musculoskeletal discomfort: effects of an office ergonomics workplace and training intervention. International Journal of Occupational Safety and Ergonomics 2003; 9:491-502

[33] Rugulies R, Raff J, Frank JEW, Oust B, Gillen M, Yen I, Bhatia R, Ames G, Gordon DR, Anoints I, Oman D, Jacobs BP, Blanc P. The psychosocial work environment and musculoskeletal disorders: design of a comprehensive interviewer-administered questionnaire. American Journal of Industrial Medicine 2004; 45:428-39

[34] Statistics Sweden: ${ }^{1)}$ Living Conditions Survey: report No 95, No 97 (1999-2004 in Swedish) ${ }^{2)}$ Living Condition Survey ('ULF'=undersökning om levnadsförhållanden 2002, in Swedish) 3) Work Force Survey ('AKU'=arbetskraftsundersökning 2008, in Swedish) www.scb.se

[35] The National Institute of Public Health, 2008, (Statens Folkhälsoinstitut, in Swedish), Olof Palmes gata 17, SE10352 Stockholm, Tfn/Phone + $46(0) 856613500$. www.fhi.se

[36] The Social Insurance Board in Sweden, 2008, http://www.forsakringskassan.se

[37] Vilnai-Yavetz I, Rafaeli A, Schneider Yaacov C. Instrumentality, Aesthetics, and Symbolism of Office Design. Environment and Behaviour 2005;37:533

[38] Wahlstrom J, Lindegard A, Ahlborg G Jr, Ekman A, Hagberg M. Perceived muscular tension, emotional stress, psychological demands and physical load during VDU work. Int Arch Occup Environ Health 2003; 76:584-90

[39] Waldenstrom K, Lundberg I, Waldenstrom M, Harenstam A, MOA Research Group. Does psychological distress 
influence reporting of demands and control at work?

Occupational and Environment Medicine 2003;60:887-91.

[40] Woods V. Work-related musculoskeletal health and social support, Occupational Medicine (London) 2005;55:17789

Ulrich S R Effects of interior design on wellness: theory and recent scientific research. $J$ Health Care Inter Des.1991;3:97-109 